\title{
Impact of Corporate Social Responsibility on Youths Empowerment in Niger Delta Region of Nigeria
}

\author{
Matthew Ayodele Olatunle ${ }^{1}$, Adamu Micah Gumus ${ }^{1, *}$, Lazarus Zungwe Wanjuu ${ }^{2}$ \\ ${ }^{1}$ Department of Management Studies, College of Business and Management Studies, Kaduna Polytechnic, Kaduna, Nigeria \\ ${ }^{2}$ Department of Social Sciences, College of Administrative and Social Science, Kaduna Polytechnic, Kaduna, Nigeria
}

Email address:

adamumicah203@gmail.com (A. M. Gumus)

${ }^{*}$ Corresponding author

\section{To cite this article:}

Matthew Ayodele Olatunle, Adamu Micah Gumus, Lazarus Zungwe Wanjuu. Impact of Corporate Social Responsibility on Youths Empowerment in Niger Delta Region of Nigeria. Journal of Human Resource Management. Vol. 8, No. 1, 2020, pp. $39-48$. doi: $10.11648 /$ j.jhrm.201200801.16

Received: February 15, 2020; Accepted: February 28, 2020; Published: March 10, 2020

\begin{abstract}
This paper examines the impact of corporate social responsibilities practice on youth's empowerment in Niger Delta Region. A descriptive and survey research design was adopted for the study. The total population of the youth within the four LGAs was estimated at 793,175 based on the 2006 census estimate extracted from the website of National Population Commission (NPC), out of the population a sample size of 384 Youths were drawn as sample size using Krejcie and Morgan (1970) table for determining sample size. Structured questionnaire was the primary instrument used for data collection. A total of 384 copies of questionnaire were administered to the respondents only 340 questionnaires were returned while 44 were not returned. Data collected were analysed using multiple regression statistical tools with the aid of SPSS version 23 to minimize errors. Findings from the study show that, social amenities and employment opportunity were found to have significant statistical relationship with youth empowerment in Niger Delta Region while scholarship scheme and skill acquisition were found to be negatively related and of no significant effect on youth empowerment. The study therefore recommends among others that, Management of the oil companies should concentrate their efforts toward embarking on good CSR practices that will have direct bearing on youth empowerment. When youth are gainfully empowered its advantages to the company, society and government are enormous.
\end{abstract}

Keywords: Corporate Social Responsibility, Skill Acquisition, Youth Empowerment

\section{Introduction}

Globally, Youths are known as the leaders of tomorrow. They play a crucial role in the prospect for development and should be included in all national development plans and programmes. Youth are one of the greatest assets any nation can have. Not only are they legitimately regarded as future leaders, they are potentially and actually greatest investment of a country's development. They serve as the good measure of the extent to which a country can reproduce and sustain itself. The extent of their vitality, responsibilities and roles in the society is positively correlated with the development of their country [1]. Young people's contribution to the advancement of the society cannot be over-emphasized since they occupy a very strategic position in the society, they are the future and hope of any nation; hence a nation that neglects her youth, trades her future [2]. The power of the youth to drive global development was recognized in 1965 by member states of the United Nations. In Nigeria, the roles of the youth in national development have been acknowledged as they continue to play pervasive roles in nation building [3-5]. Curtain [6] defined youth as an economic and social concept referring to a separate stage in the lifecycle between childhood and adulthood. United Nations Habitat [7] defined youth as people with the ages of 15-32 years. Commonwealth Secretariat [8] in their analysis of young people refers to youth as person between ages of 15-29 years old. Furthermore, the Nigerian government characterizes youth as ambitious, enthusiastic, energetic and promising. Igbo and Ikpa [9] say that, youths are filled with energy and when this energy is positively channeled or 
guarded, they are highly productive, and hence likely to contribute to the overall development of the society. On the other hand, when the energy is negatively channeled, restiveness and its resultant effects are likely to be felt. In order to effectively and efficiently maximize the potentials of Nigerian Youth, there is need for government at all levels, corporate organisations and Non-Governmental Organisations (NGOs) to embark on strategic youth empowerment programmes.

Youth empowerment is a process where young people are encouraged to take charge of their lives. They do this by addressing their situation and then take action in order to improve their access to resources and transform their consciousness through their beliefs, values, and attitudes [10]. Youth empowerment is achieved through participation in youth empowerment programmes. The need to empower youths for a better tomorrow is connected both, to the financial elevation as well as increment of the standard of living. In view of the significance of youth empowerment, most organisations today embark on youth empowerment programmes through corporate social responsibility (CSR). These involves a range of activities such as working in partnership with local communities, empowering youth to; curb youth restiveness; particularly socially sensitive investment; develop relationships with employee, customers and their families; and get involved in activities for environmental conservation and sustainability [11].

The inability of government alone to empower the youths is so disturbing. Thus precipitating a situation where social problems are multiplying rapidly in Nigeria [12]. According to Langhout and Thomas [13], the concept of empowerment is critical to the development of youths' ability to recognize themselves as stakeholders in their community and as participants in civic engagement. However, organisations or programmes with goals to foster ideals of empowerment face myriad challenges, such as the social and environmental context of the youths, and the status that the youth strive to maintain in their communities [12]. Most of these programmes provided by some of these organisations or group were not properly packaged to meet the needs and expectations of the youths. As such, most of the youth remained disempowered and contributed to the high number of unemployed youths in Nigeria. To confirm this ugly situation, the NBS report of Nigeria in fourth quarter (Q4) 2017 has shown that, there is 7.9 million Nigerian youths aged 15-34 that are currently unemployed [14]. The continuous increase in the army of these unemployed youth gives way to youth restiveness particularly in the Niger Delta. Also, an increase in the occurrence of acts of violence and lawlessness, including hostage-taking of prominent citizens and expatriates in oil/gas industry, as well as oil bunkering, arms insurgence, cultism, etc. all these social vices are major problems that organisations, government and citizens of Nigerians have to contend with as a result of high rate of youth unemployment. The questions on the lips of most Nigerians include: has organisations use CSR strategies to curb youth restiveness within Niger Delta? What are the corporate social responsibility programmes that organizations provide for youths empowerment and how has it impacted on youths' well-being? These questions remained unresolved and required further investigation. Therefore, the overall aim of this study is to explore and examine the contribution of corporate social responsibility practiced by companies within the Niger Delta Region and its impact on youth empowerment Specifically, the study investigates the following:

i. To assess the basic social amenities provided by companies and their impact on youth empowerment.

ii. To find out the scholarship scheme offered by companies and their impact on youth empowerment.

iii. To identify the employment opportunities provided by companies and its impact on youth empowerment.

iv. To verify the skill acquisition programmes carried out by the companies and to assess their impact on youth's empowerment.

In order to give this study a clear direction, the null hypotheses of the study was formulated in concordance with the above set out objectives.

i. $\mathrm{H}_{01}$ : Social amenities provided by organisations have no significant effect on youth's empowerment within the Niger Delta Region

ii. $\mathrm{H}_{02}$ : Scholarship scheme offered by organisations has no significant effect on youth empowerment within the Niger Delta Region

iii. $\mathrm{H}_{03}$ : Employment opportunity provided by organisations has no significant effect on youth's empowerment within the Niger Delta Region

iv. $\mathrm{H}_{04}$ : Skill acquisition programmes practiced by organisations have no significant effect on youth's empowerment within the Niger Delta Region

\section{Concept of Corporate Social Responsibility (CSR)}

Although there are many definitions of CSR available, we centre our attention on more recent concepts of CSR [15]. Although the concept of CSR is widely discussed in theory and practice (Weber, 2008) a universally accepted definition of CSR is yet to emerge [16]. CSR has been conceptualised differently by individuals [17]. Indeed Amaeshi and Adi [18] argue that there are as many definitions of CSR as there are writers on the topic. Malovicsa, Csigene, Noemi and Kraus [19] opined that CSR is centred on the notion that the business sector should not only concentrate on profit-oriented commercial activities but also play a noneconomic role in society. It is the manager's duty or obligation to make a decision that nurtures, projects, enhances and promotes the welfare and wellbeing of stakeholders and society as a whole [20]. Kotler and Lee [21] express that corporate social responsibility is a commitment to improving community well-being through discretionary business practices and contributions of corporate resources. McWilliams and Siegel [22] defined CSR as actions that appear to further some 
social good, beyond the interests of the firm and that which is required by law. Important in this definition is that CSR activities are on a voluntary basis, going beyond the firm's legal and contractual obligations. European Commission [7] defined Corporate Social Responsibility as a concept whereby companies integrate social and environmental concerns in their business operations and in their interaction with their stakeholders on a voluntary basis

As such it involves a wide range of activities such as being employee-friendly, environment-friendly, and mindful of ethics, respectful of communities where the firms' plants are located, and even investor-friendly [23]. Ademosu [24] sees CSR as what an organization does to contribute to the social, economic, political or educational development of the community where it is located, but which it is not compelled to do by any law. Furthermore, CSR has been thought of as a non-coercive instrument that allows corporations to discharge civic advantages beyond what the law does or does not stipulate. According to Davis [25], CSR usually goes beyond the law with the motive of benefiting both the society and the corporation. Carroll [26] came up with a model for CSR that included economic, legal, ethical and discretionary responsibilities. In 1983, Carroll further renamed discretionary responsibilities as philanthropic responsibilities and suggested that the four dimensions of economic, legal, ethical and discretionary responsibilities must be applied to the corporation to obtain a socially responsible behaviour.

\subsection{Youth Empowerment in Nigeria}

Youth empowerment is an attitudinal, structural, and cultural process whereby young people gain the ability, authority, and agency to make decisions and implement change in their own lives and the lives of other people, including youth and adults [27].

Youth empowerment does not only mean to providing jobs alone to the youth but, also, extended to cover political, economic, intellectual and social power. This makes the youth to have that sense of belonging. Empowerment makes the youths to be better placed to function multi-facedly to achieve the holistic goals of the society. Youth empowerment is often addressed as a gateway to intergenerational equity, civic engagement and democracy building [28]. Nigerian youth are change agents. Empowering them makes them to be equipped with various skills, values, attitudes, and orientation that will impact on their lives, the lives of others and the society in general. Youth empowerment therefore is the programme that is oriented or designed to make youths to be more economically and socially responsible and selfreliant, via business and vocational skills acquisition through technical and managerial training [28]. Hence the need to empower the Nigerian youths in order for them to live a meaningful life and to contribute to societal growth and harmonious peace is of essence.

\subsubsection{Corporate Social Responsibility and Youth Empowerment}

Corporate social responsibility is a strategic tool that is being employed by organization to obtain a favourable response from their stakeholders; youth are also part of these business stakeholders [12]. This justifies why most companies and business are re-strategising their corporate social responsibility activities to empowering the youth. Most companies are coming to term with the fact that youth are vital segment of the society that determine peaceful society that sustain economic growth, empowering such youths will amount to stimulating them actively into the business cycles. Ocran [29] identified two categories of CSR; Internal and external while socially responsible practices that mainly deal with employees and related to issues such as investing in human capital, health and safety and management change, while environmentally responsible practices related mainly to the management of natural resources and its usage in production are internal. External CSR beyond the company into the local community and involves a wide range of stakeholders such as business partners, suppliers, customers, public authorities and NGOs that representing local communities as well as environment.

Few empirical studies have examined the effect of CSR activities on youth empowerment in Niger Delta for instance, the study conducted by Ogula [30] examined the effect of CSR on youth expectation in the Niger Delta and the result of the study shows that CSR have positive and significant effect on youth empowerment. Similarly, Fasanya and Onakoya, [31] investigated the role of CSR on youth empowerment by multinational companies in Nigeria and the study found that CSR is a significant predictor of youth empowerment.

\subsubsection{Social Amenities and Youth Empowerment}

Social amenities are human needs considered to be essential to make life easier and more pleasant. In most countries government provides basic amenities, such as roads, running water, hospital, schools, recreation centers and electricity to improve the quality of life of the members of the given society [32]. However, nowadays the situation is gradual changing. Thanks to the increasing number of enterprises that profess CSR values many social amenities arose. Social responsibility of companies led them to develop new technologies, innovations and infrastructure that can be used by every member of society including the youths [33]. Corporations that share their hard earned investment, contribute to the advancement and empowerment of youth through the provision of social amenities have recognized the vital role of CSR as a marketing tool hence, there continues commitments in CSR is in the increase based on their perceived value on CRS.

\subsubsection{Scholarship Scheme and Youth Empowerment}

Scholarship scheme is a philanthropic gesture provided by an individual, group's members, and government agent or business enterprise in enhancing the quality life of the beneficiary. Organisations embark on provision of scholarship scheme as a corporate social responsibility with the aim to foster social and educational inclusion through the upliftment of underserved youths through the support of educational scholarships and ICT empowerment programs. It 
is important to note that youths make up a vast majority of the world's population and therefore play a crucial role in the production and consumption patterns of our global business world. Furthermore, in less than three (3) generations, 41\% of the world's youth will be Africans, of which Nigerians make up $1 / 6$ th of that demography. Additionally, $43 \%$ of Nigerian youths are below the age of 35 years while $60 \%$ have attained at least a secondary level education with only $32 \%$ having access to the internet, and only about one-third owning a cell phone [14]. These statistics indicate a social and economic challenge that can be addressed with the right empowerment approach. Therefore, corporate organizations have identified the significant role of empowering youths through scholarship scheme to cover various areas of training needs of the youth.

\subsubsection{Employment Opportunity and Youth Empowerment}

Moreover, corporate social responsible exhibited by companies through job employment may inspire youth in their surroundings to corporate with them and create a more peaceful and conducive business environment for their business to strive. Thus, social activation enables them to experience emotional benefits from being involved in helping youth [33]. It must be noted that company's success, which may be secured by implementing CSR, is also a success for youth empowerment through job opportunity. A richer company can hire more employees on better conditions, providing substantial perks [34]. As most of the workforce in the facility is usually drawn from surrounding areas, youth from local communities are provided with better employment opportunities.

\subsubsection{Skill acquisition and Youth Empowerment}

Skills acquisition has been described by many as the recipe for eradicating extreme poverty and hunger by creating avenues for employment, thereby creating an avenue for jobs and wealth creation while instilling self- sufficiency and reliance [35]. Skills acquisition is the ability to learn a skill, which can be intellectual such as learning to listen, speak, read and write or manual such as learning to build or make something. Isaac [35] suggest that, skills acquisition is the key for the elimination of hunger and poverty, reduction or elimination of joblessness in the society and reduction of crime through effective engagement of youths. Youth empowerment is a process where young people are encouraged to take charge of their lives. They do this by addressing their situation and then take action in order to improve their access to resources and transform their consciousness through their beliefs, values, and attitudes. Youth empowerment aims to improve quality of life. Youth empowerment is achieved through participation in youth empowerment programs. Grownder [35] argued that companies expand their CSR toward empowering youth with various skill acquisition programs. They do this with high expectation that the youth will reciprocate their contributions and patronage their brands at all time. There are few studies that show that CSR involving the use of skill acquisition has contributed significantly on youth empowerment.

\subsection{Empirical Review}

Wisdom (2014) examined the impact of CRS programme on youth empowerment in Yenagoa, Nigeria. The study used survey research design and the data analysis was based on primary data through the administration of questionnaire to 7000 beneficiaries of the programme in Yenagoa. Data was analyzed in tables and simple percentages, the hypotheses were tested using Chi-Square. It was found that CSR has positive and significant impact on youth empowerment.

Soreh [36] examined corporate social responsibility and youth's restiveness in oil rich Niger Delta Region of Nigeria and found that youth perception of poor CSR performance by the oil companies is a major reason for youths' restiveness in Niger Delta region of Nigeria. He further argued that effective and efficient application of corporate social responsibility by oil and gas companies operating in the region would go a long way in reducing the level of youth restiveness, improve infrastructural development and sustainable peace in the Niger Delta region of Nigeria.

Owoeye and Yara (2011) conducted a study in Ekiti State, Nigeria to determine how CSR proxies by provision of health facilities and social amenities in school contribute to academic performance of youth schools. Using descriptive survey design of the ex-post factor type, the study determined that school social amenities and health and amenities have an effect on academic performance of youth. The study therefore argued that provision of academic and social amenities was paramount if the community were to have higher expectations in academics performance of the youth. The findings in this study corroborated the findings of sardauna and Mustapha (2011) who argued that social amenities affected children's cognitive development and therefore directly influenced their academic performance.

Sanjo, Abimbola and Gabriel (2017) investigated the effect of CSR programme as an effective tool on youth empowerment towards the initialization of sustainable development in an economy. The CSR activities include skill acquisition, provision of social facilities and job opportunities for youth. Descriptive research design was used in the study and copies of questionnaire were distributed to 300 beneficiaries of CSR activities in Cameroon. Ordinary least square regression was used to analyze the data collected. Result analyzed showed that there is a positive significant relationship between skills acquisition programme and poverty reduction.

Ilemona, Akoji, and Agoha, (2016) provide a framework that shows the antecedence and impact of CSR on youth empowerment in Kogi State of Nigeria. The study made use of primary data collected with the aid of a well-structured questionnaire, which were administered by well-trained enumerator to beneficiaries of CSR program randomly sampled from six Local Government Area of the state. The data collected through the questionnaire was analyzed using descriptive statistics like frequencies and percentages. The result shows that $65 \%$ of the respondents accepted that lack of provision of CSR activities to youth is responsible for the 
high rate of poverty in Nigeria. The result also revealed that at least $60 \%$ of the people that benefitted from some forms of CSR intervention can now afford the basic necessity of life. While the study shows a positive result, the study fails to identify its sample size; the study used a weak statistical tool which the result may have been more robust if analytical tool like SPSS and other tools are used.

Bodisere and Baikwe, (2017) examined CSR programs by selected banks in Delta State: Implication for youth restiveness using descriptive survey design with a sample of 460 respondents. The researcher employed purposive sampling technique to select respondents (only youths) for the study. The data obtained was analyzed using mean and standard deviation and the findings showed that the extent to which CSR program is carried out in Bayelsa state by the selected deposit banks is low; the extent to which youth in Bayelsa state assess CSR programs is very poor and the extent to which youth are empowered in Bayelsa is discouraging.

Yusuf and Kawuwa (2014) evaluated CSR programme on youth empowerment using infrastructural development, provision of scholarship and skill acquisition as the major proxies for CSR. Data for the study were generated through questionnaire and in-depth interview. The sample sizes of one hundred and five (105) respondents were randomly selected from each of the three programmes; the selection was done using the simple random sampling technique, which involves using the table of random numbers to select respondents from the population. One hundred beneficiaries were selected through proportionate sampling and

CSR Independent Variables administered with questionnaire. While five (5) officials from the Borno state ministry of poverty alleviation and Youth Empowerment were selected for an in-depth interview. In all one hundred and five respondents took part in the study. Simple mean and percentage table was used to analyse the data and the result did not show a positive and significant relationship between CSR and youth empowerment.

\subsection{Theoretical Framework}

According to Post [37], the stakeholder theory is a strong approach in explaining and interpreting CSR practice, this has indeed become one of the most important and frequently cited theories in the literature. It is upon this theory that this present study hinges.

Stakeholder theory suggests that organisational survival and success is contingent on satisfying both its economic (e.g., profit maximization) and non-economic (e.g., corporate social performance) objectives by meeting the needs of the company's various stakeholders [38]. According to this approach, paying attention to the needs and rights of all the stakeholders including youths in a business is a useful way of developing socially responsible behaviour by managers [39]. A socially responsible organisation is seen as one in which obligations to stakeholders figure prominently in the decision-making of managers [40]; [41]. Hence, this theory will be adopted because, its theoretical interpretation suggest that socially responsible organization will provides social welfare such as scholarship, employment opportunities, skill acquisition, sporting activities to its relevant stakeholder, the youth.

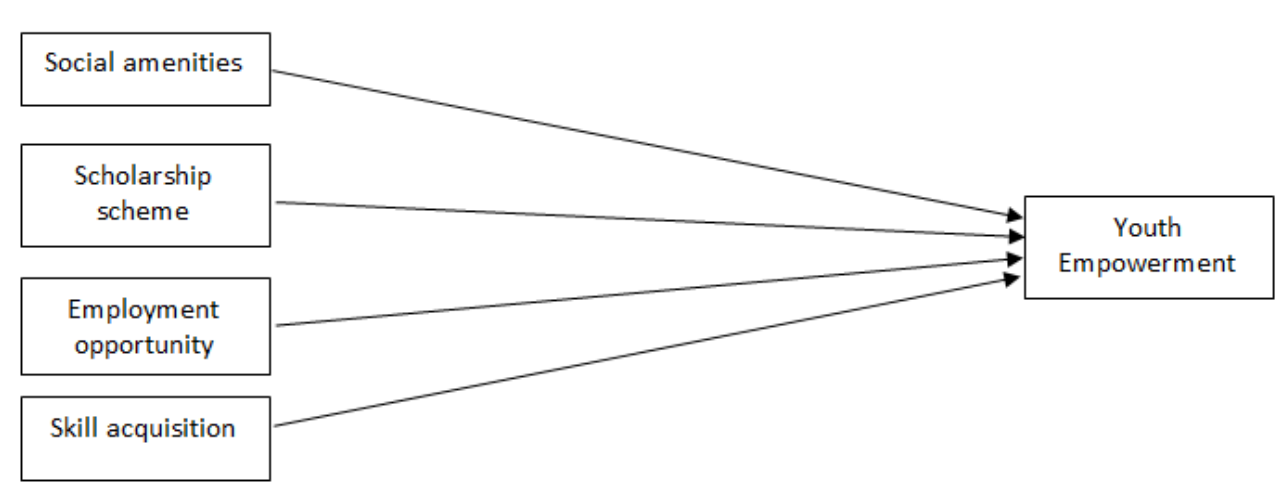

Source: The Researcher

Figure 1. Conceptual Framework.

\section{Research Methodology}

This study used the cross-sectional research design which is often called sample survey research design. The population of this study consists of four (4) Local Government Areas, namely; Ahoada East and Abua Local Government Areas, both in Rivers State. As well as, Yenagoa and Brass Local Government Areas are in Bayelsa State. The choice of these two LGAs from River State is that, they are communities hosting the oil field project of NDEP Company while, the other two LGAs from Bayelsa State are hosting oil field project of Bayelsa Oil Company. The total population of the youth within the four LGAs was estimated at 793,175 based on the 2006 census estimate extracted from the website of National Population Commission (NPC). The details of all the youth that make up the population is shown in the table hereunder. 
Table 1. List of selected LGs from Bayelsa and River States.

\begin{tabular}{lllll}
\hline S/N & States & Local Governments & Age Distribution & Youth Population \\
\hline 1 & Bayelsa & Brass & $0-39$ & 147460 \\
2 & Bayelsa & Yenagoa & $0-39$ & 287063 \\
3 & River & Abua-Odual & $0-39$ & 225666 \\
4 & River & Ahoada-West & $0-39$ & 132986 \\
5 & Total population of Youth & & 793,175 \\
\hline
\end{tabular}

Source: National Population Commission (2006 Census)

The study used an estimated sample size of 384 Youth shown in table 2, which was drawn from Krejcie and Morgan (1970) table for determining sample size. Proportional sampling technique was used to create a fair representation for all the youths within the four LGs, while convenience sampling technique was employed to select the number of Youths from each LGA.

Table 2. List of Youth Used for the Study.

\begin{tabular}{|c|c|c|c|}
\hline $\mathbf{S} / \mathbf{N}$ & Names of Local Governments selected & Number of Youths & Percentage $(\%)$ \\
\hline 1 & Brass & 72 & 18.59 \\
\hline 2 & Yenagoa & 139 & 36.20 \\
\hline 3 & Abua-Odual & 109 & 28.45 \\
\hline \multirow[t]{2}{*}{4} & Ahoada-West & 64 & 16.76 \\
\hline & Total & 384 & 100 \\
\hline
\end{tabular}

Source: Population estimate of Youths from each LGA.

The study used questionnaire as the major instrument designed for data collection. The questionnaire was structured objectively into two major sections. Section A of the questionnaire contained the demographic data of the respondents while, section $\mathrm{B}$ captures the inferential data used to measure the variables. Items measuring four independent variables were adapted from the study of Saleem and Gopinath [42] while the item measuring the dependent variable was adapted from the study of Hasoneh and Alafi
[43]. Also, five items were used to measure each of the variables which represent the independent and dependent variables in the study. All the items were measured using a 5 point Likert scale ranging from strongly agreed to strongly disagree. Data collected from respondents were further analysed using multiple-regression analysis with the aid of SPSS version 2.0. The choice of using this method is as a result of the multi-variance of the independent variable.

\section{Discussion of Findings}

Table 3. Regression Result 1.

\begin{tabular}{|c|c|c|c|c|c|c|c|c|c|}
\hline \multicolumn{10}{|c|}{ Model Summary $^{\mathrm{b}}$} \\
\hline \multirow{2}{*}{ Model } & \multirow{2}{*}{$\mathbf{R}$} & \multirow{2}{*}{ R Square } & \multirow{2}{*}{$\begin{array}{l}\text { Adjusted } \\
\text { R Square }\end{array}$} & \multirow{2}{*}{$\begin{array}{l}\text { Std. Error of the } \\
\text { Estimate }\end{array}$} & \multicolumn{5}{|l|}{ Change Statistics } \\
\hline & & & & & R Square Change & F Change & df1 & df2 & Sig. F Change \\
\hline 1 & $.570^{\mathrm{a}}$ & .325 & .311 & 2.74675 & .325 & 23.542 & 5 & 342 & .000 \\
\hline
\end{tabular}

a. Predictors: (Constant), Social Amenities, Scholarship Scheme, Employment, Skill Acquisition, Sport Activities

b. Dependent Variable: Youth Empowerment (YE)

The result in table 3 above shows the $\mathrm{R}$ value of ' 0.570 ' or $57 \%$ which suggests a strong positive correlation between corporate social responsibility programmes and youth empowerment in Niger Delta Region. The R square value of
' 0.325 ' suggests that the entire model has explained about $33 \%$ variation of youth empowerment in Niger Delta. Hence, the remaining $67 \%$ of variation can be explained by other factors outside the model.

Table 4. Regression Result 2.

\begin{tabular}{lllllll}
\hline ANOVA $^{\mathbf{a}}$ & & & & & \\
\hline Model & & Sum of Squares & Df & Mean Square & F & Sig. \\
\hline \multirow{3}{*}{1} & Regression & 1123.484 & 5 & 224.697 & 28.627 & $.000^{\mathrm{b}}$ \\
& Residual & 2700.062 & 344 & 7.849 & & \\
& Total & 3823.546 & 349 & & & \\
\hline
\end{tabular}

a. Dependent Variable: Youth Empowerment

b. Predictors: Social Amenities, Scholarship Scheme, Employment, Skill Acquisition, Sport Activities

The result in table 4 above reveals the regression equation represented by a set of regression coefficients that in total, are statistically significant from zero shows an ' $\mathrm{F}$ cal' of
28.627 and a significance value of 0.000 (or $\mathrm{p}<.01$ ). This indicates the fitness of the model and the implication is that corporate social responsibility programmes provided by the 
two companies are strong factors that influence youth empowerment in Niger Delta Region.

Table 5. Regression Result 3.

\begin{tabular}{|c|c|c|c|c|c|c|}
\hline \multicolumn{7}{|c|}{ Coefficients $^{\mathrm{a}}$} \\
\hline \multirow{2}{*}{\multicolumn{2}{|c|}{ Model }} & \multicolumn{2}{|c|}{ Unstandardized Coefficients } & \multirow{2}{*}{$\begin{array}{l}\text { Standardized Coefficients } \\
\text { Beta } \\
\end{array}$} & \multirow{2}{*}{$\mathbf{T}$} & \multirow{2}{*}{ Sig. } \\
\hline & & $\mathbf{B}$ & Std. Error & & & \\
\hline \multirow{5}{*}{1} & (Constant) & 8.192 & .533 & & 15.357 & .000 \\
\hline & Social Amenities & .383 & .039 & .511 & 9.915 & .000 \\
\hline & Scholarship Scheme & .096 & .038 & .150 & 2.505 & .013 \\
\hline & Employment & .198 & .052 & .259 & 3.790 & .000 \\
\hline & Skill Acquisition & -.003 & .079 & -.004 & -.044 & .965 \\
\hline
\end{tabular}

a. Dependent Variable: Youth Empowerment

\subsection{Test of Hypothesis One}

$\mathrm{H}_{01}$ : Social amenities offered by organisations has no significant effect on youth empowerment within the Niger Delta Region.

The result in table 5 shows the effect of social amenities on youths empowerment within the Niger Delta Region. The beta weight of scholarship scheme was .511 with a positive P-value of $0.000 \quad(\mathrm{p}<.01)$, which suggests that social amenities provided by the two companies are strong corporate social responsibility activities that influences youths empowerment within the Niger Delta Region. Thus, the null hypothesis which stated that social amenities offered by organisations has no significant effect on youth empowerment within the Niger Delta Region is rejected while the alternative hypothesis which states that social amenities provided by organisations has significant effect on youths empowerment within the Niger Delta Region. The result of this study therefore agrees with the findings

\subsection{Test of Hypothesis Two}

$\mathrm{H}_{02}$ : Scholarship scheme offered by organisations has no significant effect on youth empowerment within the Niger Delta Region.

The result in table 5 shows the effect of scholarship scheme on youths empowerment within the Niger Delta Region. The beta weight of scholarship scheme was .150 with a negative P-value of 0.013 ( $p>.01$ ), which suggests that scholarship scheme provided by the two companies is not a corporate social responsibility activities that influences youths empowerment within the Niger Delta Region. Thus, the null hypothesis which stated that Scholarship scheme offered by organisations has no significant effect on youth empowerment within the Niger Delta Region is accepted while the alternative hypothesis is rejected. The result of this study therefore agrees with the findings

\subsection{Test of Hypothesis Three}

$\mathrm{H}_{03}$ : Employment opportunity provided by organisations has no significant effect on youth's empowerment within the Niger Delta Region.

Also, the result in table 5 shows the effect of employment opportunity on youth's empowerment within the Niger Delta Region. The beta weight of scholarship scheme was .259 with a positive $\mathrm{P}$-value of $0.000(\mathrm{p}<.01)$, which suggests that employment opportunity provided by the two companies is a strong corporate social responsibility activity that influences youth's empowerment within the Niger Delta Region. Thus, the null hypothesis which stated that Scholarship scheme offered by organisations has no significant effect on youth empowerment within the Niger Delta Region is rejected while the alternative hypothesis which states that employment opportunity provided by organisations has significant effect on youth's empowerment within the Niger Delta Region. The result of this study therefore agrees with the findings

\subsection{Test of Hypothesis Four}

$\mathrm{H}_{01}$ : Skill acquisition programs practiced by the organisations have no significant effect on youth's empowerment within the Niger Delta Region.

In table 5 the result shows the contribution of skill acquisition programme on youth's empowerment within the Niger Delta Region. The beta weight of skill acquisition programme was -.004 with a negative P-value of 0.965 $(\mathrm{p}>.01)$, which suggests that skill acquisition programmes provided by the two companies is not a corporate social responsibility activities that influences youths empowerment within the Niger Delta Region. Thus, the null hypothesis which stated that skill acquisition programmes practiced by the organisations have no significant effect on youth's empowerment within the Niger Delta Region is accepted while the alternative hypothesis is rejected. The result of this study therefore agrees with the findings.

Consequently, the research model is expressed as follows:

$$
\begin{gathered}
\mathrm{Y}=\beta 0+\beta 1 \mathrm{X} 1+\beta 2 \mathrm{X} 2+\beta 3 \mathrm{X} 3+\beta 4 \mathrm{X} 4+\epsilon \\
\mathrm{Y}=8.192+.383 \mathrm{X} 1+.096 \mathrm{X} 2+.198 \mathrm{X} 3+.003 \mathrm{X} 4+\epsilon
\end{gathered}
$$

The objective of this research study is to examine the effect of corporate social responsibility (skill acquisition, employment opportunity, scholarship scheme and social amenities) on youth empowerment in Niger Delta Region. A model of regression was developed that was statistically significant at $99 \%$. The results indicate that skill acquisition, employment opportunity and social amenities jointly contribute $57 \%$ to youth empowerment in Niger Delta Region. Also, multiple regression analysis was carried out to determine the most contributory explanatory variable that best predicts youth empowerment in Niger Delta Region and 
only two of the variables: social amenities and employment opportunity were found to have significant statistical relationship with youth empowerment in Niger Delta Region while scholarship scheme and skill acquisition were found to be negatively related and of no significant effect on youth empowerment.

The findings further indicate that skill acquisition shows an insignificant effect on youth empowerment in Niger Delta Region. This indicates that the effort of the two companies toward provision of skill acquisition has not been felt by the youth of the respective community which has discouraged the youths from responding positively toward skill acquisition provided by the two companies. This implies that the youth are not satisfied with the efforts made by the companies within their communities as regard to skill acquisition program. Hence, there is need for the companies to intensify effort by providing the necessary skills that meet the need and aspirations of the youths and improve on their CSR particularly in the area of skill acquisition, this will help and improve on the corporate image of the companies.

Also, findings reveal that scholarship scheme provided by the two companies has a negative and insignificant effect on youth empowerment. This indicates that the two companies have not done much in providing scholarship to youths to support them in their various areas of studies. Their failure to provide the youth with the required scholarship within the communities was expressed by the responses made by the youth. Despite the large number of the youth $(63.2 \%)$ with SSCE/WAEC and NCE/ND certificates that could be helped to further their education through effective scholarship programme, the companies seem not doing enough in this area of corporate social responsibility. Hence, there is need for companies operating at Niger Delta Region to introduce scholarship scheme in their CSR mix to help in curbing youth restiveness, promote peace and guarantee stable business environment within the communities they operate.

Similarly, findings indicate that employment opportunity shows positive effect on youth empowerment in Niger Delta Region. This suggests that, the companies have also gained favourable response from the youth as regard their effort in employing youths within the communities where the companies operates when vacancies exist in their companies. This is a major strategy employed by these companies to protect their companies from attacks by angry youths within the communities. More so, if youth are meaningfully engaged their youthful energy will be directed toward higher productivity.

Finding from the study showed that social amenities provided by the companies have a positive impact on youth empowerment within the Niger Delta Region. This suggests that the companies have committed much of their effort toward the provision of social amenities within the communities which has been felt by the youths. The finding of this study is in agreement with the findings of Wisdom (2014) and Yusuf and Kawuwa (2014) that found that CSR has positive and significant impact on youth empowerment.

\section{Conclusion and Recommendations}

The study was carried out to examine the effect of CSR on youth empowerment in Niger Delta Region. Four hypotheses were developed for the study and the scope of the study was limited to four local government areas, two in Bayelsa State and two in River State. Their responses were collected and multiple regression analysis was used to analyse the data. The study found that, social amenities and employment opportunity has positive significant effect on youth empowerment, while skill acquisition and scholarship have no significant effect on youth empowerment in Niger Delta Region.

Based on the findings of the results, the study recommends that:

1. Management of the two oil companies should concentrate their effort toward embarking on good CSR practices that will have direct bearing on youth empowerment. When youth are gainfully empowered its advantages to the company, society and government are enormous.

2. Management of the two companies must put in place a good scholarship scheme tailored to the needs of the youths in their respective field of studies which will provide training and development opportunity for majority of the youths within their community. This will provide the opportunity for the less privilege youths to obtain their desired training need.

3. Management of the two companies should deploy measures on how to provide skill acquisition programmes like; tailoring, soap making, carpentry, shoe making among others, this will provide youths with the necessary skills that will keep them busy and less restive there by empowering the youth.

4. There is room for further improvement by the companies on their current level of performance in regards to the provision of employment opportunities and social amenities despite the overwhelming support of programmes by the respondents. These CSR programmes could be extended to all youths in the state thereby providing a sense of belonging and empowerment to all.

\section{References}

[1] National Youth Policy (2009). National Youth Policy and Strategic Plan of Action. Retrieved on January 21st, 2016 from http://www.youthpolicy.com/Policies/Nigeria\%20National\%20 Youth\%20Policy\%20\&\%20Plan\%20of\%20Action.pdf.

[2] Ojeleye, Y. C. (2016). Youth Perspective to Corporate Social Responsibility Programmes among Telecommunications' Companies in Zamfara state. The $11^{\text {th }}$ International Conference on Research and Innovations for Sustainable Development at the Rivers State University of Science and Technology, Port Harcourt, Nigeria 6th-7th December, 2016.

[3] Akpabio, I. (2005). "Human Agriculture Social Themes in Agricultural Development". Abaam publishing Co., Uyo. 
[4] Ajayi A. R. (2006)."A Guide for Young Farmer Clubs Programme". SAC Impressions, Akure.

[5] Gobeli, V. C. (1995). "Youth Development, Part of a Comprehensive Strategy for Sustainable Development in Developing Countries". An Expert Consultation on Extension Rural Youth Programme and Sustainable Development, Food and Agricultural Organization, Rome. 65-78.

[6] Curtain, R. (2001). Youth and Employment: A Public Policy Perspective. Development Bulletin. 55 (1); 7-11. Retrieved on August 24th, 2015 from

http://curtainconsulting.net/download_controlled/Youth $\% 20 \%$ 26\%20Development/youthpol.pdf.

[7] United Nations Habitat (2001). Retrieved on December 28th, 2015 from

http://www.unhabitat.org/pmss/listItemDetails.aspx?publicatio $\mathrm{nID}=33938$.

[8] Commonwealth Youth Development Index (2013). Retrieved on January 17th, 2016 from

http://youthdevelopmentindex.org/views/faq.php.

[9] Igbo, H. I \& Ikpa, I. (2013). Causes, Effects and Ways of Curbing Youth Restiveness in Nigeria: Implications for Counselling. Journal of Education and Practice. Vol, 4 (6), 131-137.

[10] Chike, P. E. \& Onyene, V. (2010). Youth restiveness in the Niger Delta of Nigeria: Implication for education and leadership. European Journal of Social Sciences. Vol. 18 (2), $286-296$

[11] Enwereonye, E. N. Ugorji, K. O. Alozie, S. T. \& Awurumibe N. U. (2015). The impact of corporate social responsibility (CSR) in community development: the gains of social work practice. International Journal of Innovative Social Sciences and Humanities Research, 3 (3), 13-17.

[12] Kohlfeldt, D., Chhun, L., Grace, S., \& Langhout, R. (2011). Youth empowerment in context: exploring tensions in schoolbased yPAR. American Journal of Community Psychology, 47, $28-45$.

[13] Langhout, R., \& Thomas, E. (2010). Imagining participatory action research in collaboration with children: An introduction American Journal of Community Psychology, 46, 60-66.

[14] National Bureau of Statistics (2017). Labour Force Statistics Volume I: Unemployment and Underemployment Report. Retrieved file:///C:/Users/USERPC/Downloads/q4_2017__q3_2018_unemployment_report.pdf.

[15] Mohamed, M. B. \& Sawandi, N. B. (2015). Corporate Social Responsibility (CSR) Activities In Mobile Telecommunication Industry: Case Study Of Malaysia.

[16] Turker, D. (2009). How corporate social responsibility influences organizational commitment. Journal of Business Ethics, 89, 189-204.

[17] Griffin, J. J. (2000). Corporate social performance: Research directions for the 21st century. Business \& Society, 39 (4), 479-491.

[18] Amaeshi, K., \& Adi, B. (2005). Reconstructing the corporate social responsibility construct in Cultish. Nottingham: International Centre for Corporate Social Responsibility.

[19] Malovicsa, G., Csigene, Noemi, N., Kraus, S. (2008). The role of corporate social responsibility in strong sustainability". The
Journal of Socio-Economics, 37; 907-918.

[20] Rahman, M. (2008). Ethics and Multinational Companies in Developing Countries. Journa

[21] Kotler, P. \& Lee, N. (2006). Corporate social responsibility: doing the most good for your company and your cause. Hoboken: John Wiley.

[22] McWilliams, A. \& Siegel, D. (2001). Corporate social responsibility: A theory of the firm perspective. Academy of Management Review. 26 (1), 7-127

[23] Benabou, R., \& Tirole, J. (2010). Individual and corporate social responsibility. Economica, Vol, 4 (77), 1-19.

[24] Ademosu, E. A. (2008). Corporate social responsibility: The experience of the Nigeria banking system. Retrieved on 21/05/2018, from http://www.acamb.coml.

[25] Davis, K. (1973). The case for and against business assumption of social responsibilities. Academy of Management Journal, June, 312-322.

[26] Carroll, A. B. (1979). A three-dimensional Conceptual Model of Corporate Social Performance. Academy of Management Review, 4 (4), 497-505.

[27] Vavrus, J., \& Fletcher, A. (2016). Guide to Social Change led by and with Young People. The Freechild Project.

[28] Snehendu, B. K.; Catherine, A. P.; Kirstin, L. C. (1999). Empowerment of women for health promotion: a metaanalysis". Social Science \& Medicine. 49 (11): 1431-1460.

[29] Ocran, E. (2011). The effect of Corporate Social Responsibility (CSR) on Profitability of Multinational Companies. A Case Study of Nestle Ghana Limited. Kwame Nkrumah University of Science and Technology. Business Enterprises, 8 (1); 136 - 149.

[30] Ogula, D. (2012). Corporate social responsibility: Case study of community expectations and the administrative systems, Niger Delta. The Qualitative Report, 17 (Art. 73), 1-27. Retrieved from http://www.nova.edu/ssss/QR/QR17/ogula.pdf

[31] Ferrell, O. C. (2004). Business ethics and customer stakeholders. The Academy of Management Executive, Vol. 18 (2), 126-129.

[32] Gulyas, A. (2009). Corporate social responsibility in the British media industries: Preliminary findings. Media, Culture \& Society, 31 (4), 657-680.

[33] Carroll, A. B. \& Buchholtz, A. K. (2009). Business and Society: Ethics and Stakeholder Management, (7th edn). Mason, OH: South Western Cengage Learning.

[34] Księżak, P. (2016). The Benefits from CSR for a Company and Society. Journal of Corporate Responsibility and Leadership, 3 (4), 53-65.

[35] Isaac N. (2011) Skills acquisition: Tonic for Economic Empowerment [online]. Leadership Newspaper. May. Retrieved from http://leadership.ng/nga/articles/163/2011/05/22/skills_acquisi tion_tonic_economic_empowerment.html.

[36] Soreh, C. W. (2012). Corporate Social Responsibility and Youth's Restiveness in Oil Rich Niger Delta Region of Nigeria. Kuwait Chapter of Arabian Journal of Business and Management Review. 1 (7); 58-67. 
[37] Post, F. R. (2003). A response to the social responsibility of corporate management: A classical critique. Mid-American Journal of Business, 18 (1), 25-35.

[38] Pirsch, J., Gupta, S., \& Grau, S. L. (2007). A framework for understanding corporate social responsibility programs as a continuum: An exploratory study. Journal of Business Ethics, $70,125-140$.

[39] Maignan, I., \& Farrell, O. C. (2004). Corporate social responsibility and marketing: An integrative framework. Journal of the Academy of Marketing Science, vol. 32 (1), 3-19.

[40] Gibson, K. (2000). The moral basis of stakeholder theory. Journal of Business Ethics, Vol, 4 (26), 245-257.
[41] Weiss, J. W. (2003). Business ethics: a stakeholder and issues, management approach (3rd ed.). Ohio: Thomson South Wester.

[42] Saleem, F. \& Gopinath, C. (2015). Corporate Social Responsibility and Customer Behavior: A Developing Country Perspective. The Lahore Journal of Business, 4 (1), $1-22$.

[43] Hasoneh, A. \& Alafi, K. (2012). Corporate social responsibility associated with customer satisfaction and financial performance a case study with Housing banks in Jordan. Journal of Research in International Business Management, 2 (2), 027-038. 